\title{
Aspartic proteinases from Mucor spp. in cheese manufacturing
}

\author{
Sirma Yegin • Marcelo Fernandez-Lahore • \\ Antonio Jose Gama Salgado • Ulgar Guvenc • \\ Yekta Goksungur • Canan Tari
}

Received: 5 September 2010 /Revised: 10 November 2010/Accepted: 15 November 2010 /Published online: 3 December 2010

(C) Springer-Verlag 2010

\begin{abstract}
Filamentous fungi belonging to the order of Mucorales are well known as producers of aspartic proteinases depicting milk-clotting activity. The biosynthesis level, the biochemical characteristics, and the technological properties of the resulting proteinases are affected by the producer strain and the mode of cultivation. While the milk-clotting enzymes produced by the Rhizomucor spp. have been extensively studied in the past, much less is known on the properties and potential applications of the aspartic proteinases obtained for Mucor spp. Indeed, several Mucor spp. strains have been reported as a potential source of milk-clotting enzymes having unique technological properties. Both submerged fermentation and solid substrate cultivation are proven alternatives for the production of Mucor spp. aspartic proteinases. This review provides an overview on the bioprocessing routes to obtain large amounts of these enzymes, on their structural characteristics as related to their functional properties, and on their industrial applications with focus on cheese manufacturing.
\end{abstract}

S. Yegin $(\bowtie) \cdot U$. Guvenc $\cdot$ Y. Goksungur

Department of Food Engineering, Ege University,

35100, Bornova, Izmir, Turkey

e-mail: sirma.yegin@ege.edu.tr

e-mail: s.yegin@jacobs-university.de

S. Yegin $\cdot$ M. Fernandez-Lahore $(\varangle) \cdot$ A. Jose Gama Salgado

Downstream Processing Laboratory, Jacobs University,

Campus Ring 1,

28759, Bremen, Germany

e-mail: m.fernandez-lahore@jacobs-university.de

C. Tari

Department of Food Engineering, Izmir Institute of Technology,

Izmir, Turkey
Keywords Mucor spp. proteinase $\cdot$ Aspartic proteinase . Acid protease $\cdot$ Milk-clotting enzymes

\section{Aspartic proteinases-an introduction}

According to the Nomenclature Committee of the International Union of Biochemistry and Molecular Biology, proteinases are classified as hydrolyses (group 3 ) and within the subgroup 4, i.e., those which are able to hydrolyze peptide bonds. They have been divided into six mechanistic classes including cysteine proteinases, serine proteinases, aspartic proteinases, metaloproteinases, threonine proteinases, and unknown type proteinases. The threonine proteinase group is the latest that has been described (Seemuller et al. 1995). Each class has a characteristic set of functional amino acid residues arranged in a particular configuration to form the active site. Proteinases can also be subdivided into two major groups based on their ability to cleave $\mathrm{N}$ - or C-terminal peptide bonds (exopeptidase) or internal peptide bonds (endopeptidase). Further, while aminopeptidase cleave $\mathrm{N}$-terminal peptide linkages, carboxypeptidases cleave the C-terminal peptide bonds.

Aspartic proteinases (EC 3.4.23), also known as acid proteinases or aspartyl proteinases, are endopeptidases having two aspartic acid residues that are critical for their catalytic activity (Asp32 and Asp215, pepsin numbering) within their active site. Most aspartic proteinases show maximal activity at low $\mathrm{pH}$ values $(\sim 3-5)$. They are acidic in nature, having isoelectric points in the range of 3 to 4.5 . They are inhibited by pepstatin A, a hexapeptide from Streptomyces that contains two statin residues, an unusual amino acid. 
Besides, they are also inhibited by diazoketone compounds such as diazoacetyl-DL-norleucine methyl ester and 1,2-epoxy-3-( $p$-nitrophenoxy) propane in the presence of copper ions (Rao et al. 1998). Aspartic proteinases have been grouped into three families, namely pepsin $\left(\mathrm{A}_{1}\right)$, retropepsin $\left(A_{2}\right)$, and enzymes from pararetroviruses $\left(A_{3}\right)$. Structurally, most aspartic proteinases belong to $A_{1}$ pepsin family. Like other pepsin-like enzymes, aspartic proteinases are synthesized as pre-proenzymes (zymogen). After cleavage of the signal peptide, the proenzyme is secreted and autocatalytically activated (Davies 1990). Generally, the active enzyme consists of a single peptide chain of about 320-360 amino acid residues and has a molecular mass of $32-36 \mathrm{kDa}$. X-ray crystallographic analyses of various aspartic proteinases showed that they are composed of $\beta$-strand secondary structures arranged in a bilobal conformation (Aguilar et al. 1997; Claverie-Martin and Vega-Hernandez 2007). The two lobes are homologous of each other and have most likely evolved by gene duplication. The catalytic center is located between the two lobes and contains a pair of aspartic acid residues, one in each lobe, that are essential for the catalytic activity. These aspartate residues activate a water molecule that mediates the nucleophilic attack on the substrate peptide bond. Andreeva and Rumsh (2001) have found that another water molecule plays an essential role in the formation of a chain of hydrogen bonds that determines the substrate binding. The catalytic site is large enough to accommodate at least seven residues of the polypeptide substrate.

Aspartic proteinases are mainly present in animal cells, plants, molds, and yeasts but seldom in bacteria (Sumantha et al. 2006). They have been linked to a variety of physiological functions including mammalian digestion (e.g., chymosin, pepsin). Microbial aspartic proteinases can be divided into two groups: (a) pepsin-like enzymes produced from Aspergillus spp. (Vishwanatha et al. 2009) and Rhizopus spp. (Kumar et al. 2005) and (b) rennin-like enzymes produced by Mucor spp. (Fraile et al. 1981; Venera et al. 1997; Fernandez-Lahore et al. 1999; Neelakantan et al. 1999; Andrade et al. 2002; Machalinski et al. 2006), Rhizomucor spp. (Thakur et al. 1990; Escobar and Barnett 1993; Silveira et al. 2005; De Lima et al. 2008), and Endothia parasitica (Sardinas 1968).

Aspartic proteinases were the first type of enzymes known to mankind, the first proteinase type described, the second protein crystallized, and also the target for numerous early investigations by the pioneers of modern enzymology and protein chemistry (Szecsi 1992). For example, bovine chymosin - in the form of calf rennethas been used for millennia in cheese making, dating back to approximately $6000 \mathrm{BC}$.

\section{Selective and high-quality biosynthesis of aspartic proteinases from Mucor spp.}

Mucorales are ubiquitous, morphologically simple terrestrial fungi. This order comprises Rhizopus, Mucor, Rhizomucor, Absidia, and Cunninghamella as members. Both Mucor spp. and Rhizomucor spp. are well-known producers of aspartic proteinases with high milk-clotting activity. These two species distinguish from each other in terms of some morphological traits and the optimum cultivation temperature, Rhizomucor spp. being of a thermophilic nature. Rhizomucor pusillus and Rhizomucor miehei are a common industrial source of microbial rennets. Fraile et al. (1981) claimed that the utilization of commercially available heat-stable enzymes in cheese manufacturing may be limited due to undesirable changes in the organoleptic quality of the final product. It is interesting to note that attempts have been made to reduce the thermostability of microbial rennets by genetic engineering approaches. For example, Yamashita et al. (1994) prepared, by site-directed mutagenesis, a $R$. pusillus mutant gene which expressed an active enzyme having a much lower thermostability than the wild-type enzyme. The mentioned recombinant proteinase was expressed in yeast. Table 1 summarizes the characteristics of some microbial aspartic proteinases.

Several reports described the efficient biosynthesis of aspartic proteinases by Mucor spp. strains (Belyauskaite et al. 1980; Fraile et al. 1981; Handel and Fraile 1984; Fernandez-Lahore et al. 1998; Andrade et al. 2002). Fraile et al. (1978) performed a pioneering study on the ability of Mucor spp. strains to synthesize milk-clotting enzymes. A collection of 41 strains were tested out of which 28 strains turned out to be active producers of such proteinases. Some of the producer strains were identified as Mucor racemosus, Mucor fragilis, Mucor mucedo, Mucor spinosus, Mucor rouxii, Mucor varians, Mucor bacilliformis, and Rhizomucor hiemalis. Further and more detailed studies focused on the biosynthesis of aspartic proteinases by $M$. bacilliformis (Areces et al. 1992), M. varians var Pispek (Bernardinelli et al. 1983), M. mucedo (Handel and Fraile 1984), and Mucor renninus (Belyauskaite et al. 1980). Tubesha and Al-Delaimy (2003) studied 20 Mucor spp. environmental isolates originating from Jordan. The highest milk-clotting activity was obtained from the so-called Mucor J120 in a solid cultivation medium containing wheat bran and lentil straw. Although no complete information on the taxonomical classification of the isolates at the species level was provided, this study confirms the potential of Mucor spp. for the biosynthesis of aspartic proteinases. Other authors (Alves et al. 2005) have observed the biosynthesis of extracellular proteinases by M. racemosus f. chibinensis and also by Mucor circinelloides f. circinelloides, M. circinelloides f. griseo-cyanus, $M$. circinelloides $\mathrm{f}$. janssenii, M. circinelloides f. lusitanicus, Mucor genevensis, 
Table 1 Characteristics of some microbial aspartic proteinases

\begin{tabular}{|c|c|c|c|c|c|}
\hline Fungi & Molecular mass (kDa) & Optimum temperature $\left({ }^{\circ} \mathrm{C}\right)$ & Optimum pH & $\mathrm{p} I$ & Reference \\
\hline Rhizomucor pusillus & 38.5 & 55 & 5.6 & 3.9 & Etoh et al. (1979) \\
\hline Rhizomисоr miehei & $20-43$ & $58-62$ & $5.6^{*}$ & 4.1 & $\begin{array}{l}\text { Preetha and Boopathy (1994), } \\
\text { Etoh et al. (1979) }\end{array}$ \\
\hline Mucor hiemalis & - & - & $3.0-3.5$ & - & Wang (1967) \\
\hline Mucor renninus & 35 & - & 3.5 & 5.1 & Belyauskaite et al. (1980) \\
\hline Mucor varians Pispek & - & - & 3.0 & - & Bernardinelli et al. (1983) \\
\hline Mucor rouxii & 16 & 50 & 4.0 & - & Diaz and Ruiz Herrera (1987) \\
\hline Mucor bacilliformis & $32-35$ & 45 & $3.0-3.5$ & 5.2 & $\begin{array}{l}\text { Areces et al. (1992), Venera et al. (1997), } \\
\text { Machalinski et al. (2006) }\end{array}$ \\
\hline Mucor circinelloides & 33 & - & $3.0-3.5$ & 4.2 & Fernandez-Lahore et al. (1999) \\
\hline Rhizopus oryzae & 34 & 60 & 5.5 & - & Kumar et al. (2005) \\
\hline Aspergillus oryzae & 47 & 55 & 3.2 & - & Vishwanatha et al. (2009) \\
\hline Endothia parasitica & $34-39$ & - & 4.5 & 5.5 & Sardinas (1968) \\
\hline Penicillium duponti & 41 & 55 & 2.5 & 3.9 & Hashimoto et al. (1973) \\
\hline
\end{tabular}

*Enzyme having milk clotting activity (The microorganism produces different kinds of aspartic proteinases)

Mucor hiemalis f. hiemalis, M. hiemalis f. luteus, Mucor piriformis f. piriformis, M. piriformis f. nanus, M. racemosus f. chibinensis, Mucor subtilissimus, Mucor variosporus, and Mucor carbonaceus. Aspartic proteinases may have well contributed, to a larger or minor extent, to the total proteolytic activity observed in the mentioned microbial strains. Further and more focused studies are required to fully clarify this point.

Since Mucor spp. are mesophilic microorganisms, it is likely that they produce aspartic proteinases which are more sensitive to temperature than those derived from Rhizomucor spp. This concept has been proven experimentally: the R. pusillus enzyme retains $71 \%$ of its original activity when heated for $10 \mathrm{~min}$ at $55^{\circ} \mathrm{C}$ while, under similar conditions, the calf rennet and the $M$. bacilliformis aspartic proteinase retain $31 \%$ and $10 \%$ of the initial milk-clotting activity, respectively (Fraile et al. 1981). Fernandez-Lahore et al. (1999) have shown that a M. circinelloides strain (M-105) produces a wild-type enzyme with very promising characteristics, being even less heat stable than the enzyme obtained from $M$. bacilliformis cultures.

In addition to the unfavorable properties of the Rhizomucor spp. milk-clotting enzymes, these microbial strains are usually able to produce a range of other proteases and/ or enzymes, e.g., lipases or amylases. In some cases, the removal of these interfering activities can be performed by simpler methods like fractional precipitation or by negative adsorption. For example, Thakur et al. (1993) used different adsorbents including different clay minerals for the removal of unspecific proteinases and lipases from the crude enzyme extract obtained from the solid-state cultivation of R. miehei. Inactivation of undesirable enzymes by limited exposure to extreme $\mathrm{pH}$ or temperature could work under specific circumstances. On the contrary, several studies on the production of Mucor spp. aspartic proteases showed the absence of interfering enzyme activities and the absence of unwanted secondary metabolites, like antibiotics or aflatoxins in the final preparations obtained from the cultures.

Diaz and Ruiz Herrera (1987) reported on the purification and characteristics of an intracellular proteinase, obtained from washed mycelia of $M$. rouxii that was grown by submerged fermentation $(\mathrm{SmF})$ in shaking flasks. Interestingly, a large proportion (89\%) of the total proteolytic activity found in disrupted mycelia crude extract was inhibited by pepstatin $\mathrm{A}$, which indicates that aspartic proteinases are mainly responsible for such activity. This is not a common finding since the microbial intracellular space usually contains a large number of different types of proteases. Therefore, the biosynthesis of aspartic proteinases by Mucor spp. may not be limited to the secreted enzymes but may also include a large amount of proteinases which are located inside the cell.

Summarizing, the evidence gathered from literature may indicate that several Mucor spp. strains could be selective producers of aspartic proteinases that mainly depict milkclotting activity and that those enzymes also show heat sensitivity and industrially desirable characteristic during cheese manufacturing.

\section{Production of Mucor spp. aspartic proteinases by submerged fermentation}

SmF are usually carried out with a substrate, which is either dissolved or remains suspended in an aqueous medium. The utilization of different substrates can affect proteinase production. A common observation is that while simple substrates, such as casein and gelatin, yield low enzyme 
activity units, more complex substrates, such as soybean meal and wheat bran, result in higher proteinase activities (Boer and Peralta 1999; Sumantha et al. 2006). On the other hand, it has been frequently described that, in a defined medium, a protein source must be present for the enzyme to be produced (Andrade et al. 2002).

M. mucedo is unique among other Mucor spp. strains in its ability to produce a milk-clotting enzyme in submerged fermentation as opposed to solid-state fermentation (SSF). Handel and Fraile (1984) investigated the production of milk-clotting enzymes using $M$. mucedo in aerated submerged culture. Casein and cheese whey were used as sole organic nitrogen sources. The highest enzyme activity was obtained at casein concentration between $0.5 \%$ and $0.7 \%(w / v)$. The effect of different glucose concentrations $(0 \%, 0.5 \%, 1 \%$, and $2 \% w / v)$ on the enzyme synthesis was studied; the optimum concentration of glucose was $1 \%$. The effect of cations $\left(\mathrm{Fe}^{2+}\right.$, $\mathrm{Cu}^{2+}, \mathrm{Mn}^{2+}$, and $\left.\mathrm{Zn}^{2+}\right)$ and anions $\left(\mathrm{SO}_{4}{ }^{2-}\right.$ and $\left.\mathrm{PO}_{4}{ }^{2-}\right)$ on the production of enzyme was also observed. In the absence of cations, production was depressed by $40 \%$ while the lack of each anion separately exhibited little effect on enzyme synthesis. Anions showed a more pronounced effect on enzyme production in a concentration-dependent manner. However, a note of caution has to be raised when analyzing the mentioned results: Belyauskaite et al. (1980) investigated the effect of different metal ions $\left(\mathrm{Ca}^{2+}, \mathrm{Mg}^{2+}, \mathrm{Cu}^{2+}\right.$, and $\left.\mathrm{Co}^{2+}\right)$ on the activation of the proteolytic enzymes produced by $M$. renninus under submerged fermentation conditions. They found that $\mathrm{Cu}^{2+}$ strongly activated such enzymes in vitro. Summarizing, the results observed by Handel and Fraile (1984) could be a combination of microbial physiologyrelated and enzyme-activation-related effects.

Recently, studies on the production of milk-clotting enzymes by $M$. mucedo DSM 809 in submerged fermentation were conducted by Yegin et al. (2010). The maximum activity was observed after $48 \mathrm{~h}$ of cultivation at $24{ }^{\circ} \mathrm{C}$ in Erlenmeyer flasks. The optimized initial $\mathrm{pH}$ and shaking speed for enzyme production were 4.5 and $220 \mathrm{rpm}$, respectively. Glucose at a concentration of $1 \%$ $(w / v)$ was the best carbon source for the production of enzyme among the carbohydrates examined (glucose, fructose, lactose, and maltodextrin). On the other hand, casein at a concentration of $0.5 \%(w / v)$ was the selected nitrogen source in the media formulation. Under optimized conditions, enzyme levels reached $130 \mathrm{U} / \mathrm{ml}$ of fermentation broth. The inoculum type and size have also affected biomass production and the biosynthesis of the enzyme; the maximum activity was obtained with spores at a total load of $6.0 \times 10^{5}$ spores per flask. Further studies are needed in order to elucidate the nature and the characteristics of the enzyme (s) produced and to increase production levels in bioreactors.
Information on the submerged cultivation and the production of aspartic proteinases by Mucor spp. other than M. mucedo is almost inexistent. However, data obtained on the production of milk-clotting enzymes by Rhizomисor spp. are abundant and can provide some additional and useful guideline in order to understand Mucor spp. behavior. Seker et al. (1998) and Beyenal et al. (1999), who worked on the production of the aspartic proteinase from $R$. miehei, pointed out that a high glucose concentration in the fermentation media inhibited enzyme activity, as it stimulated biomass rather than rennin production. Silveira et al. (2005) also investigated the effect of carbon and nitrogen sources on rennin production by $R$. miehei in submerged fermentation. In this case, an optimized glucose concentration (18 g/l) yielded maximum enzyme activity levels, but product inhibition was detected when the glucose concentration increased to $25 \mathrm{~g} / \mathrm{l}$. High enzyme activity $(667-923 \mathrm{U} / \mathrm{ml})$ was obtained when corn step liquor and Proflo ${ }^{\circledR}$ were utilized as nitrogen source. Another study by De Lima et al. (2008) investigated the growth pattern of $R$. miehei NRRL 3420 in SmF. The production of the milk-clotting enzyme was studiedemploying statistical design methods - as a function of lactose (from cheese whey) and glucose amounts, which were added as carbon sources. The highest enzyme activity measured was $1,200 \mathrm{U} / \mathrm{ml}$ of fermentation broth. This level was obtained with a combination of $20 \mathrm{~g} / \mathrm{l}$ of glucose and $4 \mathrm{~g} / \mathrm{l}$ of casein at $\mathrm{pH}$ 4.0. When compared to glucose, lactose was considered as an inferior source of carbon for the production of rennin. As expected for a primary product of metabolism, the enzyme production was associated with cell growth. These results, taken as a whole, indicated a positive effect of glucose and other carbohydrates - up to a certain threshold - on enzyme synthesis whereas casein and other nitrogen sources induced proteinase production in Rhizomucor spp.

Additional information can be gathered from Andrade et al. (2002), who studied the production of extracellular proteinases from $M$. circinelloides using different concentrations of D-glucose $(40,60$, and $80 \mathrm{~g} / \mathrm{l})$ as a substrate. Although highest biomass production was obtained in a medium containing D-glucose at a concentration of $80 \mathrm{~g} / \mathrm{l}$, the maximum enzyme production was found when the substrate concentration was reduced to $40 \mathrm{~g} / \mathrm{l}$. According to the mentioned authors, glucose was found to be a reasonably good substrate for enzyme production, especially when used at the lowest concentration these authors have tested. However, it has been also noticed that a lack of such substrate resulted in a dramatic decrease in the enzyme production. These results suggested that $M$. circinelloides could be a promising strain for aspartic proteinase production. Parallelisms can be found between studies performed on some Rhizomucor 
spp. and Mucor spp. strains when cultivated in submerged fermentation.

The potential for scale-up of the production of aspartic proteinases from Mucor spp. is clear from the bioprocess setup mentioned by Belyauskaite et al. (1980). These authors run a submerged fermentation at the $1.5-\mathrm{m}^{3}$ scale, utilizing media composed of 3\% maize starch, $1.5 \%$ casein, $0.2 \%$ calcium chloride, and $0.05 \%$ mono-potassium phosphate ( $\mathrm{pH} 5.5)$. The sterile broth was inoculated with $3 \%$ M. renninus mycelia. Other cultivation parameters were temperature of $30{ }^{\circ} \mathrm{C}$, aeration rate of $0.85 \mathrm{~m}^{3} / \mathrm{m}^{3}$ per minute, and stirring velocity of $200 \mathrm{rpm}$. Unfortunately, no information on total milk-clotting enzyme yields was reported in this study.

\section{Production of Mucor spp. aspartic proteinases by solid-state fermentation}

SSF involves all those processes which utilize waterinsoluble material for microbial growth in the absence of free water. These conditions tend to favor the growth of filamentous fungi. The advantages of SSF include simplicity, lower production costs, high enzyme yields, and low wastewater output. An additional advantage is the facilitated recovery of the products, e.g., an enzyme can be leached out in a concentrated solution. Moreover, SSF helps to prevent phenomena that adversely influence the biosynthesis of aspartic proteinase as in the cases of catabolite repression by glucose or the case of biosynthesis inhibition by amino acids and ammonia (Fernandez-Lahore et al. 1998). Several types of aspartic proteinases have been successfully produced by this technique (Preetha and Boopathy 1994; Pandey et al. 2000; Kumar et al. 2005).

Previous studies may indicate that Mucor spp. strains are good aspartic proteinase(s) producers in solid cultures. For example, Higashio and Yoshioka (1982) screened several fungal strains and found that $M$. racemosus produced a milk-clotting enzyme reaching $6,500 \mathrm{U} / \mathrm{g}$ of solid substrate in SSF systems, which would correspond to a crude extract containing $600-1,000 \mathrm{U} / \mathrm{ml}$. As a comparison, the same strain was able to reach enzyme activity between 600 and $800 \mathrm{U} / \mathrm{ml}$ of culture supernatant after submerged fermentation. Moreover, some authors have reported that the quality of the final milk-clotting enzyme preparations obtained via SSF is improved when compared to those obtained by the SmF technique (Thakur et al. 1990).

As mentioned above, Mucor spp. strains can produce milk-clotting enzyme(s) under SSF conditions, typically yielding 5,000 U/g of solid substrate after 5-6 days of cultivation at moderate temperatures. The solid substrate mixture, the initial moisture content, the substrate $\mathrm{pH}$, the substrate porosity, the cultivation temperature, the presence of added nutrients, and the inoculum size are critical factors concerning process yields. Highest productivity can be obtained with selected strains at starting moisture level of $90 \%$ (dry weight basis), at $24-28{ }^{\circ} \mathrm{C}$, at initial acidic $\mathrm{pH}$ values, and by utilizing wheat bran as substrate (Fraile et al. 1978, 1981; Fernandez-Lahore et al. 1997). Other authors have reported that enzyme production in a supplemented wheat bran mixture was optimal by cultivating at $30^{\circ} \mathrm{C}$ and harvesting the fermented mass after 3-4 days (Tubesha and Al-Delaimy 2003). All the enzymes produced by Mucor spp. in SSF have shown remarkable heat sensitivity.

Fraile et al (1981) studied the production of milk-clotting enzyme from a $M$. bacilliformis strain (M-88) on wheat bran medium and reported on some properties of the crude extract obtained after extraction of the fermented mass with water. The peak of enzyme production was observed after $85 \mathrm{~h}$ of cultivation, reaching milk-clotting activity levels within the 3,000-4,000 U/g range. The crude enzyme had an optimal activity at $\mathrm{pH} 4.0$, which is very close to the $\mathrm{pH}$ optima of calf rennet ( $\mathrm{pH}$ 3.7). It was also mentioned that the enzyme was stable between $\mathrm{pH} 3.0$ and 6.0, as it was observed for calf rennet and the $R$. miehei proteinase. Similarly, Fernandez-Lahore et al. (1997) tested several media formulations in order to enhance the production of aspartic proteinase by $M$. bacilliformis. Durum wheat bran, bread wheat bran, rice bran, sunflower hill, and different mixtures of the substrates thereof were tested. The best results were obtained with durum wheat bran as a sole substrate. Further enrichment of the same by addition of glucose $(50 \mathrm{mg} / \mathrm{g})$, wheat flour $(10 \% \mathrm{w} / \mathrm{w})$, skim milk $(1 \%$ $w / w)$, or a cocktail of mineral ions did not improve the production of the enzyme. The optimized fermentation system - based on wheat bran wetted to $120 \%$ (wet basis) with $0.2 \mathrm{M}$ chloridric acid solution and inoculated with $5 \times$ $10^{5}$ spores per gram-produced a maximum milk-clotting activity of $7,500 \mathrm{U} / \mathrm{g}$ after $72 \mathrm{~h}$ of cultivation at $24{ }^{\circ} \mathrm{C}$. Further studies by Lareo et al. (2006) on this strain were conducted on a synthetic solid substrate. Growth and sporulation of M. bacilliformis on inert polyurethane foam at varying water activity values and nutrient concentrations were investigated. Maximum biomass $\left(0.59 \mathrm{~g} / \mathrm{g}_{\text {inert support }}\right)$ and spore production $\left(6.0 \times 10^{8}\right.$ spores per gram $\left._{\text {inert support }}\right)$ were obtained at $90 \%(w / w)$ water content. The biomass, $\mathrm{CO}_{2}$ production, and glucose consumption profiles of $M$. bacilliformis were modeled, and estimates of the corresponding kinetic parameters were obtained. Maximum specific growth rates $\left(\mu_{\max }\right)$, using the logistic and the exponential models, were determined from biomass data as 0.12 and $0.40 \mathrm{~h}^{-1}$, respectively. The same parameter was determined from $\mathrm{CO}_{2}$ evolution data as 0.14 and $0.73 \mathrm{~h}^{-1}$ depending on the model utilized to fit such data, as before. Although the logistic model fitted the $\mathrm{CO}_{2}$ data well, it did not predict the active biomass levels after carbon source 
consumption, and therefore, this model can estimate yield coefficients $\left(\mathrm{Yx} / \mathrm{CO}_{2}\right)$ and maintenance coefficients $\left(m \mathrm{CO}_{2}\right)$ with some deviations. Such parameters are useful for design and control purposes in SSF systems (Mitchell et al. 2004).

Bernardinelli et al. (1983) studied the production of the milk-clotting enzyme from $M$. varians Pispek under SSF on wheat bran. Milk-clotting activity of up to $4,000 \mathrm{U} / \mathrm{g}$ of solid substrate was achieved. The enzyme was easily leached out from the fermented mass with water as extractant and subsequently recovered by precipitation with ammonium sulfate or organic solvents (ethanol and acetone). The crude enzyme showed an optimum $\mathrm{pH} \approx 3.0$ when casein and denatured hemoglobin were used as assay substrates. This acid proteinase was fairly unstable at $\mathrm{pH}$ values higher than 7.0 and temperature values higher than $45{ }^{\circ} \mathrm{C}$. Antibiotic activity was absent, and interfering enzymatic activities, i.e., amylase and lipase were negligible or within the range encountered in other commercial products.

Fernandez-Lahore et al. (1999) reported the production, purification, and partial characterization of an aspartic proteinase derived from M. circinelloides (M-105). Durum wheat bran was utilized as solid substrate. These authors reported that the biosynthesis of the enzyme, measured via a milk-clotting assay, reached its maximum on the fourth day of cultivation. At the peak of production, an activity level of 7,100 U/g was observed. Recently, Sathya et al. (2009) tested 20 different agro-industrial residues as solid substrate to produce milk-clotting enzyme with the local isolate of $M$. circinelloides. Among the solid substrates studied, dhal husk provided maximum enzyme activity $(7,651 \mathrm{U} / \mathrm{g})$, and the yield was improved by supplementing with sucrose and yeast extract. Among all the physicochemical parameters tested, the best results were obtained in a medium with a moisture content of $20 \%$ at $\mathrm{pH} 7.0$, when inoculated with $30 \%$ of spore suspension and incubated at $30{ }^{\circ} \mathrm{C}$ for 5 days. The addition of $\mathrm{Mg}^{2+}$, $\mathrm{Ca}^{2+}$, and $\mathrm{Cu}^{2+}$ ions increased protease production, while a reduction was observed when $\mathrm{Na}^{2+}$ and $\mathrm{Zn}^{2+}$ were added. Cultivation parameters for the Mucor spp. aspartic proteinases under SmF and SSF conditions have been summarized in Table 2.

\section{Recovery and purification of Mucor spp. aspartic proteinases}

Any bio-production process, whether it involves SSF or SmF, consists of two major stages: (a) upstream operations and the cultivation process as required for enzyme biosynthesis and (b) downstream processing as required for the efficient recovery and purification of the product.
Since filamentous fungi are good exporters of proteins and enzymes to the extracellular media, the downstream processing routine in this case does not have to include a cell disruption step. The product can be recovered directly from the fermentation liquor or leached out from the solid substrate cultures. Figure 1 depicts the common sequence of unit operations utilized for the downstreaming of extracellular enzymes produced by either SmF or SSF of filamentous fungi. The final degree of purification is dictated by the application which determines the steps necessary for downstream processing.

A prerequisite for enzyme purification is the ability to recover the product in its active form and in a clarified and concentrated solution, where the mentioned macromolecule of interest is stable enough for further processing. When aspartic proteinase(s) are produced in SmF, separation of the mycelia (biomass) is performed either by centrifugation or filtration, and the subsequent clarified broth is concentrated by tangential-flow (ultra) filtration. However, an SSF-produced enzyme has to be extracted out of the solids (fermented mass), and therefore, an additional operation ("leaching") is introduced. This is an important unit operation required to prepare a concentrated crude extract by utilizing an appropriate solvent (or "extractant"). Leaching performance is affected by various factors like the pretreatment of the fermented mass, the retention of the solvent in the solids, the nature (diffusivity) of the product, the mixing regime in the extraction vessel, the contact time between phases, the system $\mathrm{pH}$ and temperature, and the leaching technique. For example, Fernandez-Lahore et al. (1998) pointed out that the leaching efficiency of a sodium chloride solution was higher than that of a non-ionic detergent solution (Triton X-100; Tween 80) or distilled water alone. Concerning the leaching operation itself, Kumar and Losanse (1987) demonstrated that the countercurrent method for solids leaching was more efficient than the percolation method.

Crude extracts or fermentation supernatants may contain more than one type of proteinase, or they may contain interfering enzyme activities and/or undesirable secondary metabolites. Belyauskaite et al. (1980) cultivated $M$. renninus via submerged fermentation and found three different proteinases with similar molecular weights (35 kDa) although only one possessed milk-clotting activity. The three proteinases depicted characteristic $\mathrm{pH}$ values with maximum proteolytic activity at $4.25,3.5$, and 2.5 , respectively. This is an exceptional finding since in most cases Mucor spp. produced only one main milkclotting enzyme, which is typically found as a main component in culture supernatants or crude extracts. In any case, unit operations based on chromatography and adsorption may be required in order to produce an adequate separation between the product and other "contaminants," 
Table 2 Cultivation parameters for the Mucor spp. aspartic proteinases

\begin{tabular}{|c|c|c|c|c|c|}
\hline Production & Strain & Max. activity & $\begin{array}{l}\text { Peak of enzyme } \\
\text { production (h) }\end{array}$ & Cultivation parameters & Reference \\
\hline \multirow[t]{5}{*}{$\mathrm{SmF}$} & M. mисеdo & $190 \mathrm{U} / \mathrm{ml}$ & 48 & $24{ }^{\circ} \mathrm{C}, 220 \mathrm{rpm}$ & Handel and Fraile (1984) \\
\hline & М. mисеdo DSM 809 & $130 \mathrm{U} / \mathrm{ml}$ & 48 & $24{ }^{\circ} \mathrm{C}, 220 \mathrm{rpm}, \mathrm{pH} 4.5$ & Yegin et al. (2010) \\
\hline & M. circinelloides & - & $96 \mathrm{~h}$ & $25^{\circ} \mathrm{C}, 120 \mathrm{rpm}, \mathrm{pH} 5.2$ & Andrade et al. (2002) \\
\hline & M. renninus & - & - & $\begin{array}{c}30{ }^{\circ} \mathrm{C}, 0.85 \mathrm{~m}^{3} / \mathrm{m}^{3} / \mathrm{min}^{\mathrm{a}}, \\
200 \mathrm{rpm}, \mathrm{pH} 5.5\end{array}$ & Belyauskaite et al. (1980) \\
\hline & M. rouxii & $0.72 \mathrm{U} / \mathrm{ml}^{\mathrm{b}}$ & 20 & $28^{\circ} \mathrm{C}$ & Diaz and Ruiz Herrera (1987) \\
\hline \multirow[t]{5}{*}{ SSF } & M. racemosus & $6,500 \mathrm{U} / \mathrm{g}$ & - & - & Higashio and Yoshioka (1982) \\
\hline & M. bacilliformis (M-88) & $4,000 \mathrm{U} / \mathrm{g}$ & 85 & $24{ }^{\circ} \mathrm{C}$, static, pH 5.5 & Fraile et al. (1981) \\
\hline & M. bacilliformis & $7,500 \mathrm{U} / \mathrm{g}$ & 72 & $24{ }^{\circ} \mathrm{C}$, static, $\mathrm{pH} 4.5$ & Fernandez-Lahore et al. (1997) \\
\hline & M. varians Pispek & $4,000 \mathrm{U} / \mathrm{g}$ & - & - & Bernardinelli et al. (1983) \\
\hline & M. circinelloides (M-105) & $7,100 \mathrm{U} / \mathrm{g}$ & 96 & $24{ }^{\circ} \mathrm{C}$, static, $\mathrm{pH} 4.8$ & Fernandez-Lahore et al. (1999) \\
\hline
\end{tabular}

${ }^{\text {a }}$ Aeration rate $\left(\mathrm{m}^{3} / \mathrm{m}^{3} / \mathrm{min}\right)$

${ }^{\mathrm{b}}$ Activity has been determined by using hemoglobin as substrate (Schlamowitz and Peterson 1959)

which are not necessarily proteins. Fernandez-Lahore et al. (1998) recovered the milk-clotting enzyme from $M$. bacilliformis from SSF crude extracts with $46 \%$ yield by employing ethanol (or acetone) precipitation at optimized $\mathrm{pH}$ values (e.g., ranging from 4.0 to 5.0). Areces et al. (1992) further purified such aspartic proteinase by employing ion exchange chromatography. Combination of various methods is a common strategy: Diaz and Ruiz Herrera (1987) purified an aspartic proteinase from M. rouxii

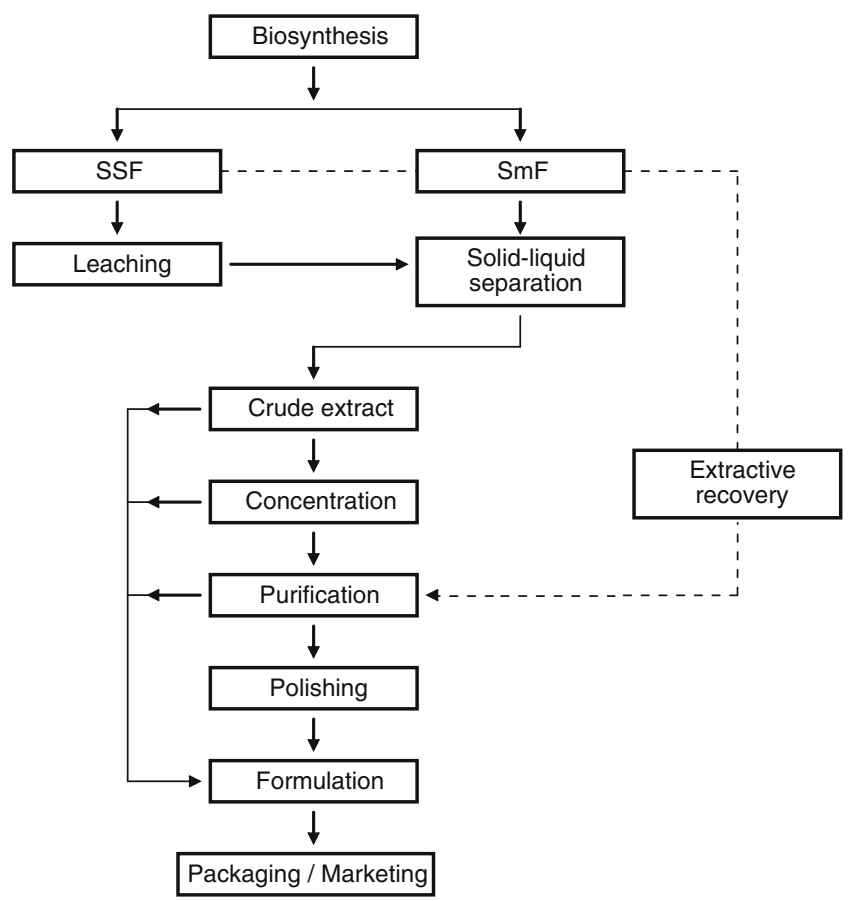

Fig. 1 An integrated sequence of operations for the downstream processing of extracellular aspartic proteinase produced by SSF and SmF systems submerged cultures by a method which involved salt and acid precipitation, anion exchange chromatography, and size-exclusion chromatography.

Crude extracts usually contain a range of secondary metabolites and inorganic salts. At industrial scale, those can be eliminated or reduced by utilizing membrane operations (ultrafiltration and subsequent diafiltration). These combined operations are the equivalent of dialysis, which is commonly employed at the laboratory scale after protein precipitation with ammonium sulfate. Another way to reduce the content of organic molecules and salts or to exchange the solution chemistry is size-exclusion chromatography; this is normally regarded as a "polishing" step. In some cases, the presence of "recalcitrant" small molecular weight organics in a complex biological mixture may induce changes in the chromatographic behavior of a targeted enzyme. Such compounds may alter the solubility and activity of these enzymes and thus negatively affect the performance of chromatographic matrices and ultrafiltration membranes by irreversible fouling. Therefore, it is advisable to implement a strategy specifically designed to sequestrate recalcitrant organics.

Fernandez-Lahore et al. (1998) designed a process aiming for the efficient and streamlined recovery of bioproducts from SSF. The aspartic proteinase from $M$. bacilliformis was utilized as a case example. The final optimized procedure consisted in the following steps: (a) leaching of the fermented mass with $1 \%$ sodium chloride solution, (b) concomitant removal of recalcitrant organics by adsorption onto low-porosity mixed-mode beaded resins, (c) concentration and diafiltration via synthetic membranes, (d) capture onto anion exchangers in finite bath. An overall purification factor of 15.5 and total enzyme yield of $46 \%$ were achieved, fitting very well with 
the standard procedures found in the literature. A similar strategy was also applied in the recovery and purification of the aspartic proteinase from $M$. circinelloides where a final yield of $76.2 \%$ and specific activity (purified enzyme) of $1,280 \mathrm{U} / \mathrm{mg}$ was obtained (Fernandez-Lahore et al. 1999). Table 3 summarizes reports on the purification strategies of aspartic proteinases from Mucorales.

The cost associated with product downstreaming and a concomitant increase in global product yields can be obtained by "integrating" recovery and purification unit operations. This concept can be materialized by replacing several traditional unit operations by a novel one which is able to deliver a similar performance. For example, the extractive recovery of enzymes in aqueous two-phase systems (Hustedt et al. 1985) can serve for the simultaneous clarification, concentration, and fractionation of a complex extract. Fernandez-Lahore et al. (1995) reported the extractive recovery and purification of $M$. bacilliformis aspartic proteinase in polymer/polymer and polymer/salt aqueous systems. Enzyme partition behavior was investigated in such systems as a function of polymer type and molecular weight, phase-forming salt type, system $\mathrm{pH}$, and sodium chloride concentration. Suitable conditions for enzyme purification were found by setting a two-step extraction/back-extraction scheme.

An enzyme solution with the appropriate level of purity has to be finally formulated, so as to guarantee product stability, potency, and standardization during final application. Formulation in the liquid and concentrated form usually considers the addition of salts, like sodium chloride, adjustment of $\mathrm{pH}$, and incorporation of various preservatives (citrate, phosphate, ammonium, alkaline metal ions, glycerol, or sorbitol). Powdered enzyme products are typically produced by spray drying in the presence of inert components (maltodextrin, polyethylene glycol, gum arabic, hydrolyzed starches, emulsifying starches, etc.). This technique can be detrimental to the activity of proteinases which are heat labile. Vacuum drying and freeze drying are available alternatives, although processing cost and enzyme stability could limit the utilization of such techniques at larger scales. Summarizing, formulation is not a trivial step and requires a proper optimization particularly with labile enzymes.

\section{Comparative structure and function of Mucor spp. aspartic proteinases}

Work describing the structural properties of aspartic proteinases derived from Mucor spp. is scarce. FernandezLahore et al. (1999) showed that the aspartic proteinase produced by solid-state cultures of $M$. circinelloides (M105 ) has a molecular weight of $33 \mathrm{kDa}$, as judged by SDSPAGE analysis and size-exclusion chromatographic experiments. A $\mathrm{p} I$ value of 4.21 was obtained by the same authors. The optimum $\mathrm{pH}$ for proteolytic activity towards dimethylcasein was within the range of 3.0 to 3.5 . Regarding thermostability, this proteinase retained $26 \%$ of its proteolytic activity at $50{ }^{\circ} \mathrm{C}$ and $13 \%$ of its proteolytic activity at $60{ }^{\circ} \mathrm{C}$ after a 30-min incubation period, at $\mathrm{pH}$ 5.0. The enzyme from the M-105 strain was fully inhibited by pepstatin A, and no effect was observed when phenylmethylsulfonyl fluoride, $p$-chloromercuriphenylsulfonate, or ethylenediaminetetraacetic acid was used. Nterminal amino acid sequence was also determined. Figure 2 shows a comparison of N-terminal sequence of M-105 strain with those from other fungal enzymes and bovine chymosin. It can be observed that Tyr14 and Gly 21 are conserved in all the proteinases compared, including the one from M-105. But it has to be pointed out that neither Try14 nor Gly21 is structurally related to substrate-bindingspecific subsite. Gly may have an important structural role since 11 Gly residues are present among the 34 invariant residues observed. Pro23 and hydrophobic residues, e.g., Val18 and Val20, are also well conserved when comparing primary sequences between proteinases.

Machalinski et al. (2006) reported the structural aspects of aspartic proteinases obtained from a mesophilic $M$.

Table 3 Strategies for purification of aspartic proteinases from Mucorales

\begin{tabular}{lll}
\hline Purification strategy & Microorganism & Reference \\
\hline Affinity chromatography, ultrafiltration, size exclusion & Mucor renninus & Belyauskaite et al. (1980) \\
Salt and acid precipitation, size exclusion, anion exchange chromatography & Mucor rouxii & Diaz and Ruiz Herrera (1987) \\
Dialysis, anion exchange chromatography & Mucor bacilliformis & Areces et al. (1992) \\
Two-phase partition & Mucor bacilliformis & Fernandez-Lahore et al. (1995) \\
Dialysis, anion exchange chromatography & Mucor bacilliformis $\quad$ Venera et al. (1997) \\
Diafiltration, anion exchange chromatography & Mucor bacilliformis & Fernandez-Lahore et al. (1998) \\
Ultrafiltration, anion exchange chromatography, size exclusion chromatography & Mucor circinelloides Fernandez-Lahore et al. (1999) \\
Filtration, ethanol precipitation & Rhizomucor miehei & Thakur et al. (1993) \\
Precipitation, dialysis, anion exchange chromatography, size exclusion chromatography & Rhizopus oryzae & Kumar et al. (2005) \\
\hline
\end{tabular}




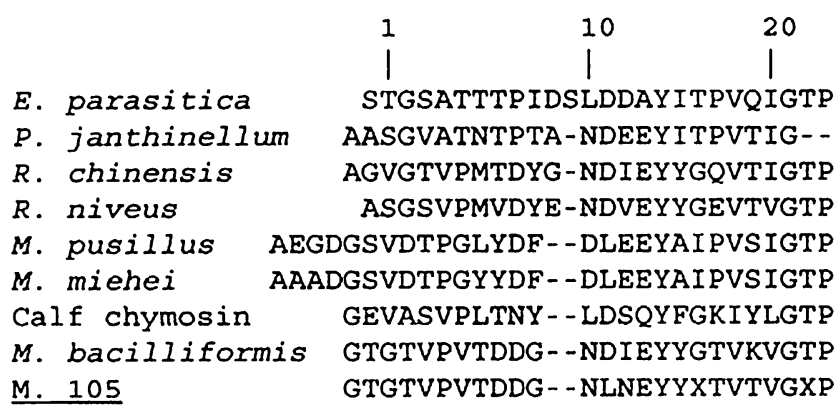

Fig. 2 Alignment of the N-terminal sequences of several fungal aspartic proteinases and calf chymosin (Fernandez-Lahore et al. 1999)

bacilliformis strain. The molecular weight of the proteinase was close to $32 \mathrm{kDa}$. The protein was monomeric, having 323 amino acid residues and four cysteine residues involved in two disulfide bridges. It is known that other members of the aspartic proteinase family have one to three disulfide bridges located at positions 251-286. The $M$. bacilliformis proteinase was reported as non-glycosylated. Although the importance of glycosylation has not been fully established for the aspartic proteinase family, it could stabilize protein conformation, thus leading to higher thermostability. In the cheese industry a low thermostability is a particularly desired rennin property so as to avoid residual proteolysis during maturation. Many commercial microbial rennet preparations are based on the milk-clotting enzymes produced by $R$. miehei. These proteinases possess higher thermostability and have large carbohydrate content (6\%, two glycosylation sites). In contrast, proteinases derived from mesophilic strains like the rhizopuspepsin from Rhizopus niveus, the pencillopepsin from Penicillium janthinellum, and the endothiapepsin from E. parasitica are not glycosylated. Sequence alignment of calf chymosin with $M$. bacilliformis proteinase revealed a $33 \%$ homology, which is higher than that of proteinases from $R$. miehei $(25 \%)$ and $E$. parasitica (26\%). The $R$. miehei rennet is currently used in cheese manufacture, thus indicating that the $M$. bacilliformis proteinase could be a useful substitute with better technological properties. Figure 3 shows the predicted 3D ribbon- type computational representation models for $M$. circinelloides and M. bacilliformis (online homology modeling with Geno3D was used to create structural models).

Venera et al. (1997) performed a detailed biochemical and kinetic study on the milk-clotting proteinase from $M$. bacilliformis. An extinction coefficient, $\varepsilon_{278} \mathrm{~cm}=$ $1.61 \mathrm{ml} \mathrm{mg}^{-1} \mathrm{~cm}^{-1}$, a molecular mass of $35.4 \mathrm{kDa}$, and $\mathrm{p} I$ of 5.2 were determined for the protein under study. The optimum temperature for proteolytic activity was $45{ }^{\circ} \mathrm{C}$. This behavior resembled bovine chymosin which has an optimum temperature of $47^{\circ} \mathrm{C}$ under the same experimental conditions. Contrarily, fungal proteinases from thermophilic strains, such as those from $R$. miehei and R. pusillus, which are extensively used in the cheese industry, have activity optima at $60^{\circ} \mathrm{C}$ and $55^{\circ} \mathrm{C}$, respectively. In the same study, optimum $\mathrm{pH}$ for peptide cleavage was determined as 3.0 and 3.5 for hemoglobin and casein, respectively. Kinetic parameters were also determined for $M$. bacilliformis aspartic proteinases as well as its susceptibility to inhibition by pepstatin $\mathrm{A}$. On the basis of the ratio of catalytic to dissociation constants $\left(\mathrm{k}_{\mathrm{cat}} / \mathrm{K}_{\mathrm{m}}\right)$ as measured on the cleavage of a peptide substrate, two subgroups of aspartic proteinases were defined: (a) a first group having $\mathrm{k}_{\mathrm{cat}} / \mathrm{K}_{\mathrm{m}}$ ratio values higher than $1,000 \mathrm{mM}^{-1} \mathrm{~s}^{-1}$, e.g., bovine and porcine pepsins and (b) a second group presenting much lower $\mathrm{k}_{\mathrm{cat}} / \mathrm{K}_{\mathrm{m}}$ ratio, e.g., Rhizopus proteinase and bovine chymosin. Catalytic efficiency of $M$. bacilliformis proteinase was found within the later subgroup since the $\mathrm{k}_{\mathrm{cat}} / \mathrm{K}_{\mathrm{m}}$ values obtained were in the 214 to $259 \mathrm{mM}^{-1} \mathrm{~s}^{-1}$ range, depending on the approach selected to perform the calculations. Thermodynamic and kinetic studies on other Mucor spp. aspartic proteinases are, at the best of our knowledge, not available in the literature.

\section{Mucor spp. aspartic proteinases in cheese manufacturing and beyond}

Aspartic proteinases can be utilized for different technological purposes. These include milk clotting during cheese
Fig. 3 The predicted 3D ribbon-type computational representation models for $M$. circinelloides (a) and $M$. bacilliformis (b)
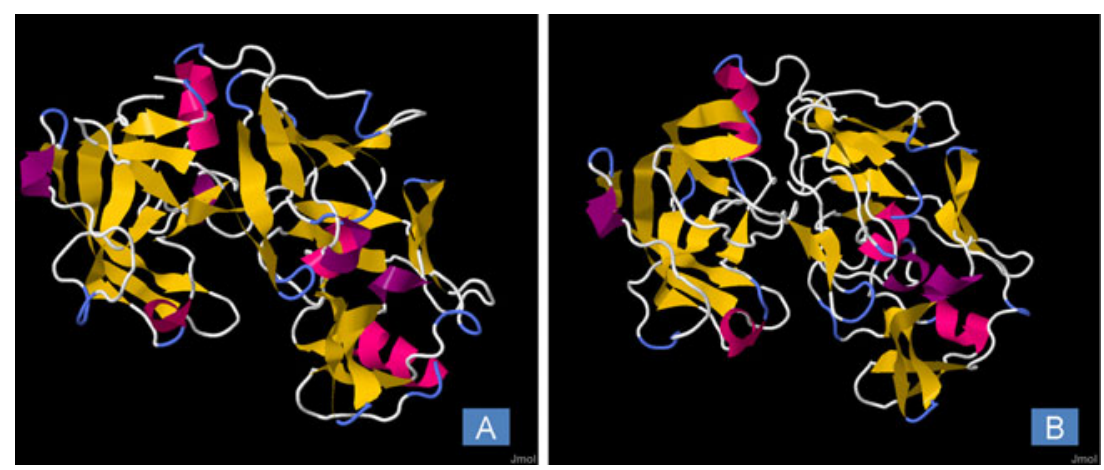
manufacturing (Claverie-Martin and Vega-Hernandez 2007), production of seasonings products (Kanlayakrit and Maweang 2006), degradation of turbidity complex resulting from protein in fruit juices and alcoholic liquors (Sumantha et al. 2006), and production of "renneted casein" and "casein hydrolysates" which are used as fat emulsifier and texture modifier agent in food and pharmaceutical formulations (Phelan et al. 2009) and also for increased fiber hydrolysis from feedstock available from agricultural processing operations (Abbas and Bao 2009), meat tenderization (Ashie et al. 2002), and peptide synthesis (Kumar and Bhalla 2005; Filippova and Lysogorskaia 2003). However, there is scarce information available on the application of aspartic proteinases other than in the cheese-making process that has been the preferred area of application until now.

Cheese production using a milk-clotting enzyme or "rennet" is the oldest attempt to extend the utilization of milk. Traditionally, bovine chymosin obtained from the abomasums of unweaned calves has been employed. The bovine "rennet" obtained from adult animals is, in contrast, rich in pepsin and has poorer technological properties. Milk-clotting enzymes are also commercially available from other mammalian species, e.g., lamb, goat, pig (Nielsen and Foltmann 1995), or from microbial sources. All of them have found well-defined applications in the dairy industry. Among the microbial milk-clotting enzymes, the ones produced by $R$. miehei and R. pusillus have gained wide industrial acceptance as substitutes for the bovine chymosin (Claverie-Martin and Vega-Hernandez 2007). However, it is well known that fungal "rennet" preparations may present a degree of tertiary (or "residual") proteolytic activity resulting in the production of bitter peptides during cheese ripening. Bovine chymosin, which remains the industrial gold standard, produces a very specific cleavage of the Phe ${ }^{105}-\mathrm{Met}^{106}$ bond of $\mathrm{K}$-casein, therefore destabilizing the casein micelle structure (Turhan and Mutlu 1998). Therefore, cleavage specificity as opposed to extended proteolysis defines a good milk coagulant.

Enzymatic milk coagulation is a two-phase process; any variation in the chemical environment can affect the two stages of reaction separately. In the first phase, the enzyme hydrolyzes the $\mathrm{K}$-casein molecule, splitting the protein into two fragments: the (hydrophobic) para-k-casein and the (hydrophilic) macropeptide. The latter is able to diffuse into the milk whey. The second phase consists of the coagulation of the casein micelles that have been destabilized by proteolytic attack (Claverie-Martin and Vega-Hernandez 2007). This phase is sensitive to temperature, medium $\mathrm{pH}$, and $\mathrm{Ca}^{2+}$ ion concentration. Figure 4 shows the mechanism of milk coagulation by bovine chymosin.

Any proteolysis caused by milk protein fractions other than the specific action on the para-K-casein is considered

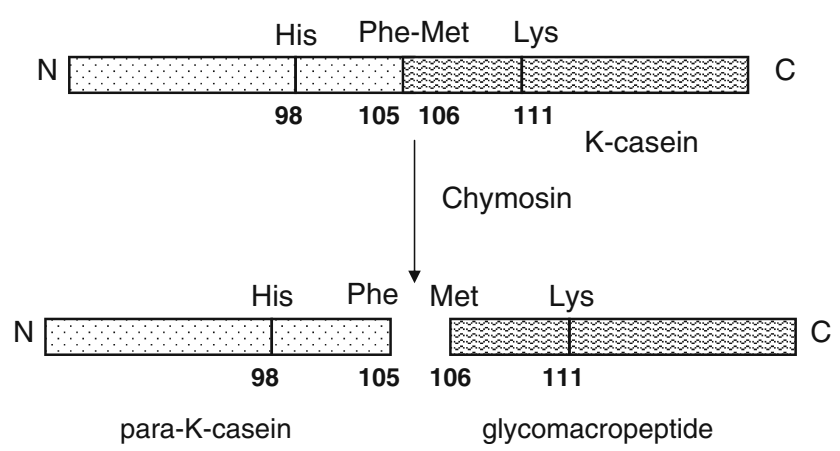

Fig. 4 Mechanism of milk coagulation by chymosin

undesirable. This phenomenon is very significant since it can be considered responsible for poor cheese quality, decreased curd yield, and economic loss. A heat-labile enzyme would be eliminated after the intended purpose of milk coagulation during subsequent manufacturing steps that may include heating. Mucor spp. aspartic proteinases presenting a high milk-clotting to tertiary proteolysis ratio and notorious thermosensitivity could find widespread application in cheese manufacturing. Recently, Sathya et al. (2009) successfully applied aspartic proteinase from $M$. circinelloides in the manufacture of cheddar cheese and compared it with the commercial rennet. Aspartic proteinase obtained from $M$. circinelloides was found to be nearly equal in yield to that made with the commercial rennet, in that 11 of cows' milk produced $163 \mathrm{~g}$ of cheese using the purified milk-clotting enzyme compared with $172 \mathrm{~g}$ produced by the commercial rennet. Tubesha and Al-Delaimy (2003) reported that the production of cheese from local isolate of Mucor J20 strains was $160 \mathrm{~g} / \mathrm{l}$ of milk sample. It has been pointed out by Fraile et al. (1981) and FernandezLahore et al (1997) that like calf rennet aspartic proteinase from M. bacilliformis and M. circinelloides loses activity with heat treatment. The milk-clotting enzyme from thermophilic fungi like $R$. pusillus kept $71 \%$ of its original activity when heated for $10 \mathrm{~min}$ at $55{ }^{\circ} \mathrm{C}$.

Aspartic proteinases from Mucor spp. have the potential to find diverse applications in the food and beverages industry and beyond, including, for example, the (bio) chemical and pharmaceutical industries. Concerning applications in food, recent progress has targeted the dairy and cheese manufacturing industries. This has been the direct consequence of understanding some of the advantageous properties of Mucor spp. proteinases, particularly thermosensitivity and limited proteolytic activity. But much effort has to go into the testing of such enzymes for many other potential niche applications.

A large number of Mucor spp. strain are readily available, but not exploited yet, for aspartic proteinase(s) production. Moreover, these strains are amenable to industrial cultivation by submerged or solid substrate 
fermentation systems. Downstream techniques are also known for the efficient recovery and purification of these enzymes. The latter may even include the utilization of affinity "tailor-made" peptides or peptide analogs as proteinase ligands. The application of classical mutation and screening technologies and genome shuffling procedures coupled to media design and efficient fermentation procedures can deliver processes depicting a high level of enzyme production. Since no genetic engineering procedures are utilized in this case, no special food labeling is required. Therefore, consumer acceptance of such products is favored.

Nowadays, it is also possible to clone the genes encoding aspartic proteinases and express them by employing host microorganisms that are well adapted to industrialscale fermentation. This approach would lead to the mass production of aspartic proteinases with unique technological properties. For example, protein engineering tools that eventually will permit further improvement (or adaptation) of enzyme properties are available. This will open a completely new era in the understanding and application of Mucor spp. aspartic proteinases.

\section{References}

Abbas CA, Bao WL (2009) Increased fiber hydrolysis by protease addition. US Patent 0098638 A1

Aguilar CF, Cronin NB, Badasso M, Dreyer T, Newman MP, Cooper JB, Hoover DJ, Wood SP, Johnson MS, Blundell T (1997) The three-dimensional structure at $2.4 \AA$ resolution of glycosylated proteinase A from the lysosome-like vacuole of Saccharomyces cerevisiae. J Mol Biol 267:899-915

Alves MH, de Campos-Takaki GM, Okada K, Ferreira Pessoa IH, Milanez AI (2005) Detection of extracellular protease in Mucor species. Rev Iberoam Micol 22:114-117

Andrade VS, Sarubbo LA, Fukushima K, Miyaji M, Nishimura K, de Campos-Takaki GM (2002) Production of extracellular proteases by Mucor circinelloides using D-glucose as carbon source. Braz $\mathrm{J}$ Microbiol 33:106-110

Andreeva NS, Rumsh LD (2001) Analysis of crystal structures of aspartic proteinases: on the role of amino acid residues adjacent to the catalytic site of pepsin-like enzymes. Protein Sci 10:2439-2450

Areces LB, Bonino MB, Parry MA, Fraile ER, Fernandez-Lahore HM, Cascone O (1992) Purification and characterization of a milk-clotting protease from Mucor bacilliformis. Appl Biochem Biotechnol 37:283-294

Ashie INA, Sorensen TL, Nielsen PM (2002) Effects of papain and a microbial enzyme on meat proteins and beef tenderness. J Food Sci 67:2138-2142

Belyauskaite IP, Palubinskas VJ, Anchenko OE, Vesa VS, Glemzha AA (1980) Purification and some properties of the extracellular aspartic proteinase from Mucor renninus. Enzyme Microb Technol 2:37-44

Bernardinelli SE, Bottaro Castilla HR, Waehner RS, Muse J, Fraile ER (1983) Production and milk clotting enzymes. Rev Argent Microbiol 15:95-104

Beyenal LH, Seker S, Salih B, Tanyolac A (1999) The effect of Dglucose on milk clotting activity of Mucor miehei in a chemostat with biomass retention. J Chem Technol Biotechnol 74:527-532
Boer CG, Peralta RM (1999) Production of extracellular protease by Aspergillus tamari. J Basic Microbiol 40:75-81

Claverie-Martin F, Vega-Hernandez MC (2007) Aspartic proteases in cheese making. In: Polaina J, Maccabe AP (eds) Industrial enzymes. Springer, Netherlands, pp 207-219

Davies DR (1990) The structure and function of aspartic proteases. Annu Rev Biophys Biomol Struct 19:189-215

De Lima CJB, Cortezi M, Lovaglio RB, Ribeiro EJ, Contiero J, De Araújo EH (2008) Production of rennet in submerged fermentation with the filamentous fungus Mucor miehei NRRL 3420. World App Sci J 4:578-585

Diaz S, Ruiz Herrera J (1987) Purification of an aspartic proteinase from Mucor rouxii that inactivates chitin synthetase. Antonie Leeuwenhoek 53:279-291

Escobar J, Barnett SM (1993) Effect of agitation on the synthesis of Mucor miehei aspartic proteinase. Enzyme Microb Technol 15:1009-1013

Etoh Y, Shoun H, Beppu T, Arima K (1979) Physicochemical and immunochemical studies on similarities of acid proteases Mucor pusillus rennin and Mucor miehei rennin. Agri Biol Chem 43:209-215

Fernandez-Lahore HM, Miranda MV, Fraile ER, de Jiménes B, Bonino MJ, Cascone O (1995) Partition behavior and purification of a Mucor bacilliformis aspartic proteinase in aqueous twophase systems. Process Biochem 30:615-621

Fernandez-Lahore HM, Fraile ER, Cascone O (1998) Aspartic proteinase recovery from solid state fermentation system. J Biotechnol 62:83-93

Fernandez-Lahore HM, Gallego Duaigues MV, Cascone O, Fraile ER (1997) Solid state production of a Mucor bacilliformis aspartic proteinase. Rev Argent Microbiol 29:1-6

Fernandez-Lahore HM, Auday RM, Fraile ER, Biscoglio De Jimenes Bonino M, Pirpignan L, Machalinski C, Cascone O (1999) Purification and characterization of an aspartic proteinase from mesophilic Mucor sp. solid-state cultures. J Pept Res 53:599-605

Filippova IY, Lysogorskaia EN (2003) Modified proteinases in peptide synthesis in organic media. Russ J Bioorgan Chem 29:544-550

Fraile ER, Bernardinelli SE, Handel M, Jauregui AM (1978) Selección de cepas de Mucor sp productoras de enzimas coagulantes de leche. Rev Argent Microbiol 10:65-69

Fraile ER, Muse JO, Bernardinelli SE (1981) Milk-clotting enzyme from Mucor bacilliformis. Eur J Appl Microbiol Biotechnol 13:191-193

Handel M, Fraile ER (1984) Production of milk-clotting enzymes by aerated submerged culture of the strain of Mucor mucedo. Acta Cient Venez 35:111-115

Hashimoto H, Iwaasa T, Yokotsuka T (1973) Some properties of acid protease from the thermophilic fungus, Penicillium duponti K1014. Appl Microbiol 5:578-583

Higashio K, Yoshioka Y (1982) Milk clotting enzyme production by N.T.G. induced mutant of Mucor racemosus no. 50. J Agri Chem Soc Jpn 56:777-785

Hustedt H, Kroner KH, Kula MR (1985) Application of phase partitioning in biotechnology. In: Walter H, Brooks DE, Fisher D (eds) Partitioning in aqueous two-phase systems, theory, methods, uses, and applications to biotechnology. Academic, Florida, pp 529-584

Kanlayakrit W, Maweang M (2006) Production of seasoning "Mirin" from Thai rice by fermentation. Kasetsart J 40:39-46

Kumar D, Bhalla TC (2005) Microbial proteases in peptide synthesis: approaches and applications. Appl Microbiol Biotechnol 68:726736

Kumar PKR, Losanse BK (1987) Extraction of gibberellic acid from dry moldy bran produced under solid-state fermentation. Process Biochem 22:139-143 
Kumar S, Sharma NS, Saharan MR, Singh R (2005) Extracellular aspartic proteinases from Rhizopus oryzae: purification and characterization. Process Biochem 40:1701-1705

Lareo C, Sposito AF, Bossio AL, Volpe DC (2006) Characterization of growth and sporulation of Mucor bacilliformis in solid state fermentation on an inert support. Enzyme Microb Technol 38:391-399

Machalinski C, Pirpignani ML, Marino C, Mantegazza A, de Jiménez Bonino MB (2006) Structural aspect of Mucor bacilliformis proteinase, a new member of the aspartyl-proteinase family. $\mathrm{J}$ Biotechnol 123:443-452

Mitchell DA, Von Meien OF, Krieger N, Dalsenter FDH (2004) A review of recent developments in modeling of microbial growth kinetics and interparticle phenomena in solid-state fermentation. Biochem Eng J 17:15-26

Neelakantan S, Mohanty AK, Kaushik JK (1999) Production and use of microbial enzymes for dairy processing. Curr Sci $77: 43-148$

Nielsen PK, Foltmann H (1995) Purification and characterization of porcine pepsinogen $\mathrm{B}$ and pepsin. Arch Biochem Biophys 322:417-422

Pandey A, Soccol CR, Nigam P, Soccol VT, Vadenberghe LPS, Mohan R (2000) Biotechnological potential of agro-industrial residues: II cassava bagasse. Bioresour Technol 74:81-87

Phelan M, Aherne A, FitzGerald RJ, O'Brien NM (2009) Caseinderived bioactive peptides: biological effects, industrial uses, safety aspects and regulatory status. Int Dairy J 19:643-654

Preetha S, Boopathy R (1994) Influence of culture conditions on the production of milk clotting enzyme from Rhizomucor. World $\mathrm{J}$ Microbiol Biotechnol 10:527-530

Rao MB, Tanksale AM, Ghatge MS, Deshpande VV (1998) Molecular and biotechnological aspects of microbial proteases. Microbiol Mol Biol Rev 62:597-635

Sardinas JL (1968) Rennin enzyme of Endothia parasitica. Appl Microbiol 16:248-255

Sathya R, Pradeep BV, Angayarkanni J, Palaniswamy M (2009) Production of milk clotting protease by a local isolate of Mucor circinelloides under SSF using agro-industrial wastes. Biotechnol Bioprocess Eng 14:788-794

Schlamowitz M, Peterson LU (1959) Studies of the optimum $\mathrm{pH}$ for action of pepsin on "native" and denaturated bovine serum albumin and bovine hemoglobin. J Biol Chem 234:3137-3145
Seemuller E, Lupas A, Stock D, Lowe J, Huber R, Baumeister W (1995) Proteasome from Thermoplasma acidophilum: a threonine protease. Science 268:579-582

Seker S, Beyenal H, Ayhan F, Tanyolac A (1998) Production of microbial rennet from Mucor miehei in a continuously fed fermenter. Enzyme Microb Technol 23:469-474

Silveira GG, Oliveira GM, Ribeiro EJ, Monti R, Contiero J (2005) Microbial rennet produced by Mucor miehei in solid state and submerged fermentation. Braz Arch Biol Technol 48:931-937

Sumantha A, Larroche C, Pandey A (2006) Microbiology and industrial biotechnology of food-grade proteases: a perspective. Food Technol Biotechnol 4:21-220

Szecsi PB (1992) The aspartic proteases. Scand J Clin Lab Invest 210:5-22

Thakur MS, Karanth NG, Nand K (1990) Production of fungal rennet by Mucor miehei using solid state fermentation. Appl Microbiol Biotechnol 32:409-413

Thakur MS, Karanth NG, Nand K (1993) Downstream processing of microbial rennet from solid state fermented moldy bran. Biotechnol Adv 11:399-407

Tubesha ZA, Al-Delaimy KS (2003) Rennin like milk coagulant enzyme produced by local isolate of Mucor. Int J Dairy Technol 56:237-241

Turhan M, Mutlu M (1998) Kinetics of K-casein/immobilized chymosin hydrolysis. Enzyme Microb Technol 22:342-347

Venera GD, Machalinski C, Zumárraga H, Biscoglio De Jimenez Bonino MJ (1997) Further characterization and kinetic parameter determination of milk clotting protease from Mucor bacilliformis. Appl Biochem Biotechnol 68:207-216

Vishwanatha KS, Appu Rao AG, Singh SA (2009) Characterization of aspartic proteinase from Aspergillus oryzae MTCC 5341. Food Chem 114:402-407

Wang HL (1967) Release of proteinase from mycelium of Mucor hiemalis. J Bacteriol 93:1794-1799

Yamashita T, Higashi S, Higashi T, Machida H, Iwasaki S, Beppu T (1994) Protease with low thermostability derived from Mucor pusillus. US Patent 5332668

Yegin S, Fernandez-Lahore M, Guvenc U, Goksungur Y (2010) Production of extracellular aspartic protease in submerged fermentation with Mucor mucedo DSM 809. Afr J Biotechnol 9:6380-6386 